\title{
Estimation of Quality Parameters, Antagonistic Properties and Commercial Production of Pseudomonas fluorescens in Plant Disease Management
}

\author{
Aradhana Mishra ${ }^{1}$, Vibha Agrawal ${ }^{1}$, Ekta Kumari ${ }^{2}$ and Virendra Kumar ${ }^{3 *}$
}

${ }^{1}$ Department of Biotechnology, Shree Agrasen Kanya P.G. College, Varanasi, U.P., India

${ }^{2}$ Central Insecticides Board \& Registration Committee, Directorate of Plant Protection

Quarantine and Storage, NH-IV, Faridabad-121 001, Haryana, India

${ }^{3}$ Bioassay Division, Central Insecticides Laboratory, Directorate of Plant Protection

Quarantine and Storage, NH-IV, Faridabad-121 001, Haryana, India

*Corresponding author

\begin{tabular}{l} 
K e y w o r d s \\
$\begin{array}{l}\text { Pseudomonas } \\
\text { fluorescens, } \mathrm{pH}, \\
\text { contaminants, } \\
\text { suspensibility, } \\
\text { antagonistic } \\
\text { capability, Bio- } \\
\text { pesticide }\end{array}$ \\
Article Info \\
\hline $\begin{array}{l}\text { Accepted: } \\
15 \text { February } 2020 \\
\text { Available Online: } \\
\text { 10 March } 2020\end{array}$ \\
\hline
\end{tabular}

\section{A B S T R A C T}

Pseudomonas fluorescens is an aerobic, gram-negative, ubiquitous bacterium present in agricultural soils that is well adapted to grow in the rhizospheric as well as phyllospheric zone. An experiment was conducted at Shree Agrasen Kanya P.G. College, Varanasi, U.P. India aimed to determine the morphological features of $P$. fluorescens as well as to carry out the process and method of its commercial production of powder formulation of the bio-control agent $P$. fluorescens $1 \% \mathrm{~W} . \mathrm{P}$ for its effective use at field. Its morphology is characterized visually and microscopically by colony growth such as colony form, color, edge and Gram staining at laboratory. The quality parameters of $P$. fluorescens were checked for $\mathrm{pH}$, moisture content, cfu, suspensibility and antagonistic capability. In this paper the detail protocol have been mentioned for preparation of talc base powder formulation of $P$. fluorescens and how to check various quality parameters. $P$. fluorescens was found most effective with highest antagonistic activity against six chosen fungal pathogen that showed maximum inhibition of mycelia growth of Fusarium oxysporum (62.60 \%), Aspergillus niger (55.47\%), Rhizoctonia solani (53.8\%), Macrophomina phaseolina (52.30\%), Alternaria alternata (49.58\%) and Pyricularia oryzae (47.67\%).

\section{Introduction}

Pseudomonas fluorescens is commonly found among the predominant genera in plant microbiomes, both in the rhizophere (Bakker et al., 2013 \& Donn et al., 2015) and in the phyllosphere, Vorholt (2012); Bulgarelli et al., (2013); Rastogi et al., (2013) irrespective of host plant species. It is a well-known biopesticide that can be used to control all bacterial and fungal soil pathogen. It is naturally occurring microorganism in the 
rhizospheric zone. The $P$. fluorescens had a great potential to decrease the conventional use of chemical pesticides, while increasing crop yield. $P$. fluorescens is generally target specific and affect only the target pest and closely related organisms. Recently, there is a wide use of biological control agents either antagonistic fungi or bacteria for the environmentally plant disease control and was reported in a considerable number of studies Kiely et al., (2006).

P. fluorescens found to have positive effects on both pathosystem and growth components such as slowness of incubation period, decreasing disease intensity, or reducing the pathogenic population density in soil as well as increasing plant height, fresh and dry weight and production, Soesanto et al., (2008, 2003).

The potentiality of Pseudomonas was found effective through its root colonizing character that release a blend of exo-product with antibiotic, metal chelating, lytic, phytohormonal \& signalling activities that contribute to more environmental fitness and disease suppressive activity. Pseudomonas positively influences the response against pathogen, improving nutrient availability in soil.

Biological control of plant pathogens by antagonistic microorganisms proved to be a potential non-chemical means and is known to be a feasible and sustainable method for the management of crop diseases. Cook (1985).

Pseudomonas noticeably been observed at the root surface (i.e. rhizoplane) often forming micro colonies or discontinued biofilms in the grooves between epidermal cells, capable of endophytic colonization. Use of antagonistic microorganisms such as $P$. fluorescens against Macrophomina phseolina have been reported by several workers. Saravana et al.,
(2005); Sendhilvel et al., (2007). In the present investigation, attempts were made to test various quality parameters in talcum base powder formulation of P.fluorescens $1.0 \%$ W.P. that includes colony forming units (CFUs), pH, moisture content, suspensibility and antagonistic capability against various fungal plant pathogens.

\section{Materials and Methods}

\section{Morphological features of $\boldsymbol{P}$. fluorescens}

A pure culture of the $P$. fluorescens was streaked on King's B agar medium separately for colony development. The individual colonies were examined for shape, size, structure of colonies and pigmentation. The colony growth includes shape, color, the edge and Gram staining which was examined under laboratory conditions plated on King's B medium. Based on the morphological characters, results were observed. Morphological results showed the mean value of 10 plates. Kucuk and Kivanc (2003).

\section{Source of $\boldsymbol{P}$. fluorescens}

The pure culture of $P$. fluorescens was procured from Microbial Type culture Collection (MTCC-8904), Chandigarh, India. The bacterial culture was confirmed by the following methods.

\section{Gram staining}

The bacterial culture was confirmed by Gram staining process via transferring it on a clean slide with the help of inoculation loop and a smear was made and dried with flame heat to fix onto the slide. The smear was flooded for one minute with ammonium oxylate crystal violet. Excess stain was poured off and the slide was washed through a gentle stream of water. Iodine solution was applied and allowed to remain for one minute, then 
decolourized with 95 per cent ethyl alcohol. The smear was washed with gentle stream of water and counter stained with safranin red colour, the observations were taken with the help of microscope and photographs were taken. This culture was primarily inoculated on King's B medium [peptone 20g, dipotassium hydrogen phosphate $1.5 \mathrm{~g}$, magnesium sulphate $1.5 \mathrm{~g}$, Glycerol $10 \mathrm{ml}$, Cycloheximide 100ppm, Ampicillin 500 ppm, Chloramphenicol $12.5 \mathrm{ppm}$ maintained in 1 litre of distilled water with pH-6.2 (King et al., 1954) onto the culture plate as well as slant and prepared 10 plates for further use by streaking method. Incubation was done for 48 hrs. at $28+1{ }^{\circ} \mathrm{C}$ with $\mathrm{RH} 65 \% \pm 2 \%$ for counting and observation of colony characters and morphology of the bacterium.

\section{Method for preparation of Powder formulation of $\boldsymbol{P}$. fluorescens}

Talc based formulation of effective strain of Pseudomonas was prepared by mixing autoclaved Carboxy methyl cellulose (CMC) $5 \mathrm{~g} / \mathrm{Kg}$ and talc powder @ 1\% w/w with bacterial strains grown on King's B broth for 48 hours in an incubator shaker at $150 \mathrm{rpm}$, $28 \pm 1^{\circ} \mathrm{C}$ for 24 hours for two consecutive days. $1000 \mathrm{ml}$ of the bacterial suspension containing $2 \times 10^{9}$ colony forming units (cfu) per $\mathrm{ml}$ was added to one $\mathrm{kg}$ of the carrier (talcum powder), mixed thoroughly and left for 2-3 days for complete drying. The flow chart has been presented below for commercial production of $P$. fluorescens.

\section{Preparation of Powder formulation of P. fluorescens}

After drying of above mentioned talcum powder checking its colony forming units (CFUs) as per method. (As per standard the CFU should be $1 \times 10^{8}$ minimum)

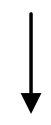

Taken $1 \mathrm{~g}$ of above mentioned powder which contains $2 \times 10^{9}$ colony forming units (cfu) per ml and then go through serial dilution up to $10^{8}$ dilutions.

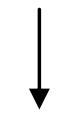

Inoculated ( $1 \mathrm{ml}$ of $10^{8}$ Soln.) above soln. in $100 \mathrm{ml}$ of King's B broth medium in conical flask.

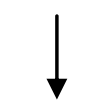

Incubated it up to 7 days in BOD at $28 \pm 1^{\circ} \mathrm{C}$.

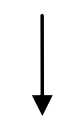

Took it out from jar and blend it with help of mixer along with King's B broth medium.

Thenmixed $100 \mathrm{ml}$ bacterial spore suspension in $1 \mathrm{~kg}$ of autoclaved talcum $+5 \mathrm{~g} \mathrm{CMC}$ (Corboxy methyl cellulose) with help of gloves in a sterilized plastic big tray or tub.

Now talcum based powder formulation of P. fluorescens, $1 \%$ W.P. is ready for used. 
The prepared powder formulation was tested again for Colony forming units (CFUs), after proper mixing the powder were packed in polythene bags \& further studied for $\mathrm{pH}$, moisture content and suspensibility for quality check.

\section{Estimation of colony forming units (CFUs)}

$1 \mathrm{~g}$ of product (Powder sample) was taken and mixed it in $10 \mathrm{ml}$ of sterilized distilled water in a clean and sterilized test tube to make $10^{-1}$ dilution $(1: 10)$. Shaked well and then $1 \mathrm{ml}$. of the suspension transferred to 9 $\mathrm{ml}$. of sterile water in a tube to make $10^{-2}$ dilution (1:100). In this way more serial dilutions was prepared up to $10^{-8}$ dilution. Transferred, $1 \mathrm{ml}$ of this suspension to sterile Petri Plates and added $15 \mathrm{ml}$ of sterilized, melted and cooled King's B media.

Rotated the plates gently and allow it to solidify. Incubation of the Petri plates placed in BOD incubator at $28^{\circ} \mathrm{C} \pm 1^{\circ} \mathrm{C}$ and R.H. at $65 \% \pm 5 \%$ was kept for 48 hours. After incubation the development of typical $P$. fluorescens colony was observed under the fluorescent illumination and then calculated the number of colony unit per gram by the below mentioned formula -

$$
\mathrm{CFU} / \mathrm{g}=\frac{\text { Average number of colonies }}{\text { Dilution factor }}
$$

\section{Estimation of $\mathbf{p H}$}

Taken $10 \mathrm{~g}$ of powder sample in $50 \mathrm{ml}$ of glass beaker \& mixed with $25 \mathrm{ml}$ of sterile distilled water. $\mathrm{pH}$ of the suspension is observed by using the $\mathrm{pH}$ meter. Three replication were taken for reading accordingly and the average value were calculated.

\section{Estimation of moisture content}

Weighted $5 \mathrm{~g}$ powdered of product and poured into beaker of $50 \mathrm{~g}$ capacity. Beaker containing weighed sample is kept in hot air oven at $65{ }^{\circ} \mathrm{C}$ for 30 minutes. After 30 minutes beaker is taken out from oven and again weigh it for determination of mass content.

$$
\text { Moisture content per cent }=\frac{(\mathrm{M}-\mathrm{m}) \times 100}{\mathrm{M}}
$$

Where,

$\mathrm{M}=$ Initial weight of product

$\mathrm{m}=$ mass of product found after hot air oven treatment.

\section{Estimation of suspensibility}

$5 \mathrm{~g}$ of powdered product was poured into beaker containing $10 \mathrm{ml}$ of hard water at 30 ${ }_{0} \mathrm{C}$ to make slurry. Then it was transferred into $250 \mathrm{ml}$ measuring cylinder by washing of beaker. Volume was making up to $250 \mathrm{ml}$ by putting hard water at $30{ }_{0} \mathrm{C}$. Homogeneous suspension was done with 30 cycle of rotation and suspension was allowed to set for 30 minutes. After settle down of suspension, 90 $\%$ of suspension $(225 \mathrm{ml})$ were be sucked off. Remaining $25 \mathrm{ml}$ suspension was being put into the oven for dry at $65{ }_{\mathrm{o}} \mathrm{C}$ temperature. Then weight was taken after oven dried of the powdered product.

Suspensibility $\%$ by mass $=\frac{1000(\mathrm{M}-\mathrm{m})}{9 \times \mathrm{M}}$

Where,

$\mathrm{M}=$ Mass in $\mathrm{g}$ of product present in the material taken for the preparation of the suspension.

$\mathrm{m}=$ Mass in $\mathrm{g}$ of product formed in suspension including the sediment remaining in graduated cylinder.

\section{Estimation of antagonistic capability}

The antagonistic effects of antagonistic bacterium i.e P. fluorescens were tested by 
dual culture technique against various pathogenic fungi. Seven days old culture of $P$. fluorescens were taken as the antagonist and pathogenic fungi against Pyricularia oryzae, Alternaria alternata, Fusarium oxysporum, Rhizoctonia solani, Aspergillus niger and Macrophomina phaseolina as a source culture of test. The culture of $P$. fluorescens was streaked with help of inoculation loop on the peripheral region of PDA Petri dish (away from $1.5 \mathrm{~cm}$ from the edge of the Petri dish) taken as a pure culture during the test. An agar block ( $5 \mathrm{~mm}$ diameter) of seven days old culture of each pathogen was prepared and inoculated at one side $(1.5 \mathrm{~cm}$ from the edge $)$ and $5 \mathrm{~mm}$ culture block of above mentioned 6 pathogenic fungi was inoculated at the opposite side of PDA Petri dish away from $1.5 \mathrm{~cm}$ from the edge of plate on the opposite side of streaked P. fluorescens.

The 5 replication were prepared for all 6 pathogenic fungi separately along with one control treatment. The inoculated Petri dishes were incubated in a BOD incubator at $28 \pm$ $2^{\circ} \mathrm{C}$ for 5-7 days. After incubation, the mycelial growth of each pathogen in all the Petri dishes was measured and calculated. The growth inhibition is calculated by using the following formula:

$$
\mathrm{I}=\mathrm{C}-\mathrm{T} / \mathrm{C} \times 100
$$

Where, I= percent growth inhibition

$\mathrm{C}=$ growth of pathogen in control (pathogen alone)

$\mathrm{T}=$ growth of pathogen in treatment (pathogen $+P$. fluorescens)

\section{Results and Discussion}

\section{Study of morphological features}

Morphological characteristics including growth, shape and colony appearance were examined. Colony appeared grown on both nutrient agar and King's B media for 3 days at room temperature was entirely different. On King's B medium bacterial colony character were found. A greenish yellow soluble diffused pigment observed into the nutrient agar medium.

On King's B medium, greenish yellow color was highly appeared around the cream colony with smooth edge, convex, glistening, entire, circular and fluorescent under the sun light that was wider as compare to colony grown on nutrient agar.

Microscopic features after stained with crystal violet showed that $P$. fluorescens was straight or rather curve rod shape with 3 or 4 flagella. When treated with $3 \% \mathrm{KOH}$, the bacterium was characterized as gram-negative rods shaped by bacterial ooze streaming. Culture of $P$. fluorescens was confirmed by Gram staining procedure. It appeared pink colour after Gram staining (Plate $1 \mathrm{~d}$ ).

\section{Preparation of powder formulation of $P$. fluorescens 1.0\% W.P.}

The proper methods had been adopted for the preparation of powder formulation of $P$. fluorescens $1.0 \%$ W.P. On the basis of method mentioned in the material and method, it was found easy to prepare the talc based bio pesticides at a commercial level and which can be used for the seed treatment, nursery treatment as well as soil treatment. The photograph are presented in Plate -1 a \& b.

Results colony forming units (CFUs), pH, moisture content and suspensibility in powder formulation

Various parameters of the tested bio-pesticide (P. fluorosens $1.0 \%$ W.P.) were calculated as standard method describe above at material \& methods and was found to have $81.25 \mathrm{x}$ $10^{6} \mathrm{Cfu} / \mathrm{g}, 64.75 \times 10^{7} \mathrm{Cfu} / \mathrm{g}, 42.5 \times 10^{8} \mathrm{Cfu} / \mathrm{g}$, 
$42.5 \times 10^{8} \mathrm{Cfu} / \mathrm{g}$ and $25.30 \times 10^{8} \mathrm{Cfu} / \mathrm{g}$ The $\mathrm{pH}$ was also calculated accordingly and the results were recorded. The $\mathrm{pH}$ of the above tested bio-pesticide was slightly alkaline $(P$. fluorosens $1.0 \%$ W.P.) i.e 7.58 and the moisture calculated as per standard oven dried method and it was found to have moisture content 8.11. (Table- 1)

Study of antagonistic capability of $P$. fluorescens against six pathogenic fungi Pyricularia oryzae, Alternaria alternata, Fusarium oxysporum, Rhizoctonia solani, Aspergillus niger and Macrophomina phaseolina

The results suggested for the combination of $P$. fluorescens $+F$.oxysporum was found to be efficient and significantly suppressed the vegetative growth of the test fungi $F$. oxysporum by restricting the hyphal growth in invitro condition with $62.60 \%$ growth inhibition followed by combination of $P$. fluorescens + A. niger with $55.47 \%$ and 53.28 $\%$ restricting the vegetative hyphal growth of Aspergillus niger and Rhizoctonia solani respectively. It was not found much effective to restrict the growth of Pyricularia oryzae where percent growth of $74.67 \%$ was recorded. The antagonistic capability of $P$. fluorescens $1.0 \%$ W.P. against the tested fungi has been presented. (Table-2)

The pure culture of $P$. fluorescens was procured from Microbial Type culture Collection (MTCC-8904), Chandigarh, India. Its traceability can be checked. $\mathrm{pH}$ is one important factor that directly affect the normal functions of unicellular and multicellular organism. Such vital functions as growth, development and cell proliferation are known to be affected by $\mathrm{pH}$ changes (Juan et al., 2019). So, in this study pH 7.58 and moisture $8.11 \%$ were found most suitable for the maximum production of colony forming units (Cfu). Corboxy methyl cellulose (CMC) was added @ $5 \mathrm{~g}$ per $\mathrm{kg}$ of talcum powder to enhance the shelf life of the finish product. The P. fluorescens $1.0 \%$ W.P. can be used as potential bio-pesticide for plant disease management. For example, it can be used against bacterial leaf blight @ $5 \mathrm{~g} / \mathrm{kg}$ of seed, tomatowilt @ $5 \mathrm{~g} / \mathrm{kg}$ of seed, carrot root rot @ 20g/kg of seed, Okra wilt @ 20g/kg of seed treatment, wilt of brinjal @ $20 \mathrm{~g} / \mathrm{kg}$ as seed treatment.

Table.1 P. fluorescens: Estimation of colony forming units (CFUs), $\mathrm{pH}$ and moisture

\begin{tabular}{|c|c|c|c|c|c|}
\hline Parameters & \multicolumn{5}{|c|}{ Estimation of CFU * } \\
\hline \multirow[t]{2}{*}{ CFU } & $10^{6}$ & $10^{7}$ & $10^{8}$ & \multicolumn{2}{|l|}{$10^{9}$} \\
\hline & 81.25 & 64.75 & 42.5 & \multicolumn{2}{|l|}{25.30} \\
\hline \multirow[t]{3}{*}{ pH } & \multicolumn{5}{|c|}{ Estimation of $\mathrm{pH} *$} \\
\hline & R1 & R2 & R3 & R4 & Mean \\
\hline & 7.56 & 7.59 & 7.62 & 7.57 & 7.58 \\
\hline \multirow{3}{*}{$\begin{array}{l}\text { Moisture } \\
\text { Content }\end{array}$} & \multicolumn{5}{|c|}{ Estimation of moisture $*$} \\
\hline & R1 & $\mathrm{R} 2$ & R3 & $\mathrm{R} 4$ & Mean \\
\hline & 8.05 & 8.12 & 8.16 & 8.12 & 8.11 \\
\hline
\end{tabular}

*Mean value of 4 replication 
Table.2 Antagonistic capability Pseudomonas fluorescens against chosen fungi

\begin{tabular}{|c|c|c|c|}
\hline S.No. & P. fluorescens \& fungal pathogen & $\begin{array}{l}\text { Radial growth of } \\
\text { fungus (mm) }\end{array}$ & $\begin{array}{l}\text { \% growth } \\
\text { inhibition }\end{array}$ \\
\hline 1. & P. fluorescens + Pyricularia oryzae & 38.2 & 47.67 \\
\hline 2. & P. fluorescens + Alternaria alternata & 36.8 & 49.58 \\
\hline 3. & P. fluorescens + Fusarium oxysporum & 27.3 & 62.60 \\
\hline 4. & P. fluorescens + Rhizoctonia solani & 34.1 & 53.28 \\
\hline 5. & P. fluorescens + Aspergillus niger & 32.5 & 55.47 \\
\hline 6. & P. fluorescens + Macrophomina phaseolina & 37.6 & 52.30 \\
\hline 7. & Control (P.fluorescens) & 80.0 & 00.00 \\
\hline
\end{tabular}

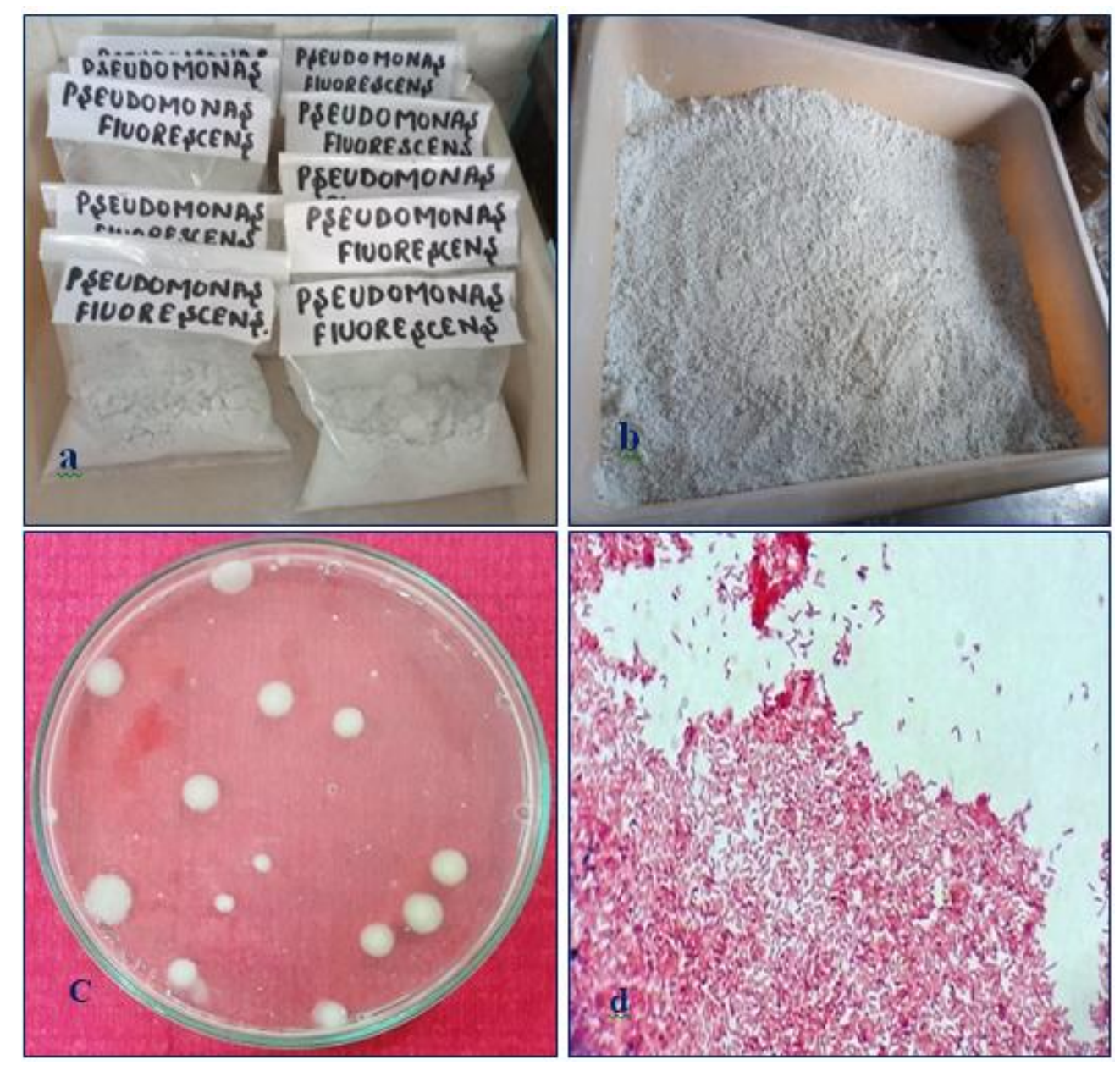

Figure.1 Commercial production of powder formulation and estimation of CFUs of $P$. fluorescens (a- Packed $P$. fluorescens for use, b- spore suspension of $P$. fluorescens mixed with talcum powder, c - Estimation of CFUs of P. fluorescens, d- Rod Shape Pseudomonas fluorescence after Gram Staining)

Beside this soil application of the $P$. of vegetable crops are very effective to fluorescens $1.0 \%$ W.P. and nursery treatment control disease from soil borne pathogen such 
as Pythium spp. Pyricularia oryzae, Alternaria alternata, Fusarium oxysporum, Rhizoctonia solani, Aspergillus niger and Macrophomina phaseolina. P. fluorecens not only controlled dry root rot, but also promoted plant growth and this give them an advantage over the use of chemical fungicides against root rot in disease management (Vanitha and Ramjegathesh, 2014).

The present study reveals strong control of disease based on the above observations in laboratory condition and the information generated through this study will help for future studies on the antagonistic effect the microorganism on soil at field condition too.

It was also observed that it control best to $F$. oxysporum, which is a very important soil fungus that causes wilt disease in various crops at both nursery as well as vegetative stage of crop. Moreover, it is suggested that during the experiment that its antagonistic capacity is very good in laboratory condition.

So, it is advisable to be use more \& more of Pseudomonas as there is an urgent need of today to replace chemical pesticides with an alternative means of bio-control agent that are safe, low in cost, local in production and also environment friendly.

Bio pesticides or biological pesticide on pathogenic microorganisms are specific to target pest offer an ecologically sound and effective solution to pest problems. They pose no threat to the environment and to human health.

\section{Acknowledgements}

Authors are very much thankful to Dr. Kumkum Malviya, Principal, Shree Agrasen Kanya P.G. College, Varanasi, U.P., India for their constant encouragement and providing the resources to carry out this research work.

\section{References}

Bakker PA, et al., 2013. The rhizosphere revisited: root micro biomics. Front Plant Sci, 4: 165.

Bulgarelli et al., 2013. Structure and function of the bacterial microbiota of plants. Annu Rev Plant Biol, 4: 807-38.

Cook RJ. 1985. Biological control of plant pathogens: Theory to application. Phytopathol, 75:25-29.

Donn et al., 2015. Evaluation of bacterial communites in the wheat crop rhizisphere. Environ Microbiol,17: 61021.

Juan A, Cervantes M, Jose Ruiz H. 2019. Identification of a novel member of the $\mathrm{pH}$ responsive pathway $\mathrm{Pal} / \mathrm{Rim}$ in Ustilago maydis. J. Basic Microbiol, 59: 14-23.

Kiely et al., 2006. Exploiting new system based stretegies to elucidate plantbacterial interaction rhizoshere. Microbiol Eco, 51:257-66.

King EO, Wood MK, Raney DE. 1954. Two simple media for the demonstration of pyocynin and luorecein. J Lab Clin Med, 44: 301-7.

Kucuk C, Kivanc M. 2003. Isolation of Trichoderma spp. and determination of their antifungal, biochemical and physiological features. Turk J Biol, 27:247-53.

Rastogi G, Coaker, GL, Leveau, JHJ. 2013. New insight into the structure and function of phyllosphere microbiota through high-throughput molecular approaches. FEMS Microbiol Lett, 110.

Saravana et al., 2007. Rhizobacterial bioformulation for the effective management of Macrophomina root rot in mungbean. Arch. Phytopathol. Pflanzenschutz, s40: 323-37.

Sendhilvel et al., 2005. Management of cowpea root-rot caused by 
Macrophomina phaseolina (Tassi) Goid. using plant growth promoting rhizobacteria. J Biol Control 19: 41-46.

Soesanto L, Hidayat R, Utami DS. 2003. Prospect of Pseudomonas fluorescnes P60 use for controlling stem rot of groundnut. Jurnal Fitopatologi Indonesia, 7:1-6. (In Bahasa Indonesia) Soesanto L, Rokhlani, Prihatiningsih N. 2008. Suppression of several antagonistic microorganisms on Fusarium wilt of gladiolus. Agrivita, 30:75-83. (In Bahasa Indonesia)

Vanitha S, Ramjegathesh R. 2014. Bio control potential of Pseudomonas fluorescens aginst Coleus root rot diseases. J Plant Pathol Microbiol, 5: 1-4.

Vorholt, JA.2012. Microbial life in phylloshere. Nat Rev Microbiol, 10: $828-40$.

\section{How to cite this article:}

Aradhana Mishra, Vibha Agrawal, Ekta Kumari and Virendra Kumar. 2020. Estimation of Quality Parameters, Antagonistic Properties \& Commercial Production of Pseudomonas fluorescens in Plant Disease Management. Int.J.Curr.Microbiol.App.Sci. 9(03): 2256-2264. doi: https://doi.org/10.20546/ijcmas.2020.903.256 